\title{
The Influence of Financial Inclusion and Macroeconomic on Foreign Direct Investment (FDI) Flows in The Organization of Islamic Cooperation (OIC) Countries
}

\author{
Farma Andiansyah ${ }^{1, a^{*}}$ \\ 1 farmaandiansyah24@gmail.com \\ ${ }^{a}$ Master of Sharia Economics, State Islamic University of Sunan Kalijaga \\ * corresponding author
}

Article history

Received 2020-08-20

Revised 2021-02-18

Accepted 2021-02-22

Keywords

Financial Inclusion

Macroeconomics

Foreign Direct Investment

Fix Effext Model
Foreign capital flows are important factors in the development of sustainable economies, especially in developing countries such as the OIC countries. Lately, the rapid development of the financial sector and macroeconomic stability became a serious concern by foreign investors, where financial inclusion and macroeconomics played an important role in attracting direct foreign capital flows (FDI). The study aims to investigate the role of financial inclusion and macroeconomic variables on the foreign direct flow of capital (FDI) by using data panels in 8 OKI member States during the 2012-2018 time span. The research uses the Fix Effect Model (FEM) Panel data Analysis tool, which is believed to be able to explain the correlation between independent variables and more accurate dependents. As for the results of the study showed that in partial only variable avaibility (the number of branches of the bank/100,000 adults) is a significant positive draws FDI in the OKI country. While on macroeconomic variables the exchange rates have significant negative effect on FDI, while interest rates and economic growth have significant positive relationships in attracting FDI.

This is an open access article under the CC-BY-SA license.

\section{Introduction}

In the era of globalization, the flow of Foreign Direct Investment (FDI) is considered as a major contributor in economic growth for developed and developing countries (World Bank Report, 2011). Many countries offer policy packages to attract inflows of foreign investment, such as China, India, and Russia offering intensive packages by implementing low tax rates, cheap labor, free trade policies, economic market orientation, good infrastructure, law order and a good security system. However, FDI inflows tend to be relatively less in developing countries and tend to be limited to developed countries. That 
is because an investor presents several specific factors related to the country of investment destination such as market size, wage level, fiscal burden, trade openness, political stability, and macroeconomic situation are major considerations for foreign investors (Karacan, 1997; Akay \&Karakay, 2008).

The research of Demirhan and Mahmut's (2008) and Qamar (2019) found empirical evidence that macro variables such as per capita GDP, inflation rate, telephone lines, labor costs, openness levels, risks and tax rates have a relationship in FDI withdrawal in developing countries. FDI is not entirely influenced by macro variables alone, some other studies have found that corporate governance and the power of trade bargaining, political stability and property rights are also efficient factors for attracting FDI (Federke \&Romm, 2006). Adam and Tweneboah (2009) and Al Nasser and Soydemir (2010) discovered a longterm relationship between FDI and financial markets. In addition, Qamruzzaman and Jianguo (2019) empirically proved the development of financial inclusion encourages the flow of foreign capital in the form of FDI to the host country.

In recent decades, developing countries are very serious in improving the level of financial inclusion in their country is no exception in the countries of the Organization of Islamic Cooperation (OIC). This is because financial inclusion greatly contributes positively to economic growth and has an important role in attracting foreign capital flows to the host country. Recently OIC countries have had very rapid growth in financial markets, banking system, and stock flows that go into FDI in unctad report (2000). Taj gardoon et al (2015) explained this through its findings that financial markets have a positive relationship with FDI. Furthermore, he explained that the development of the financial sector can stimulate the economic performance of the real sector through productive loans so that it will increase economic growth in the country.

The Organization of Islamic Cooperation (OIC) is a multilateral organization between Islamic countries followed by 57 Islamic countries from all over the world. OIC member states are made up of a variety of different economic backgrounds, there are rich countries, new industrialized countries, service-based economies, and poor countries. Many OIC developing countries rely on foreign capital sources such as FDI to support their economic growth to get out of the circle of backwardness and poverty. In 2018 FDI in OIC countries reached 104.4 billion dollars or $8.3 \%$ of the world's total FDI which reached 1.3 trillion in 2018 (SESRIC, 2019). The figure is quite large but the distribution is still concentrated in some countries only. 


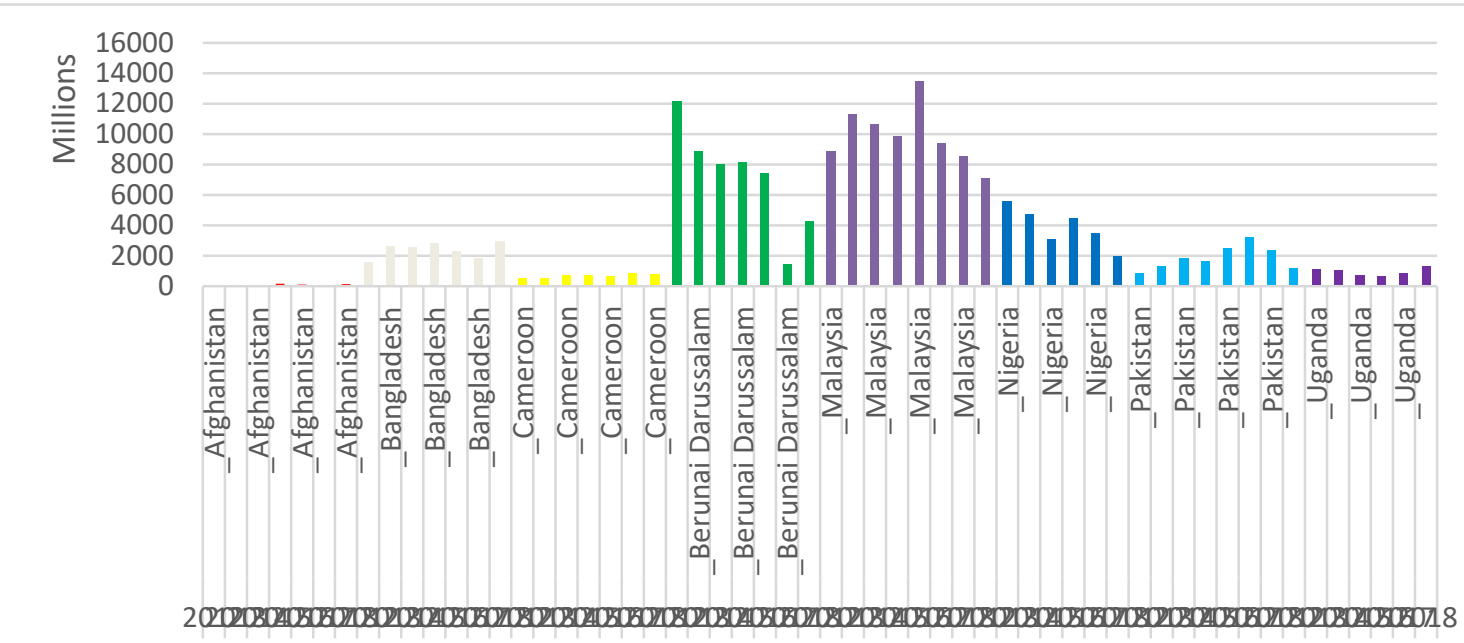

Source: World Bank (2018)

\section{Figure A.1: OIC Country FDI Flow 2012-2018}

According to a 2018 World Bank report, the amount of foreign direct investment fund (FDI) flows in some OIC countries still seems to be experiencing inequality, however, in some OIC countries the capitalization is quite large. Indonesia became the largest FDI towing country in 2018 with a capitalization of 22 billion dollars or $20.5 \%$ and Malaysia ranked fourth by attracting 7.5 billion or $7.5 \%$ of the total FDI in OIC countries, but many other developing countries with FDI flows are less than 5\% such as Afghanistan, Cameroon, Uganda and other countries. Various studies explain the determining factors of FDI in OIC countries, such as research of Sudarsono (2008) found exchange rates, inflation and trade openness have a significant role in the withdrawal of FDI in OIC countries.

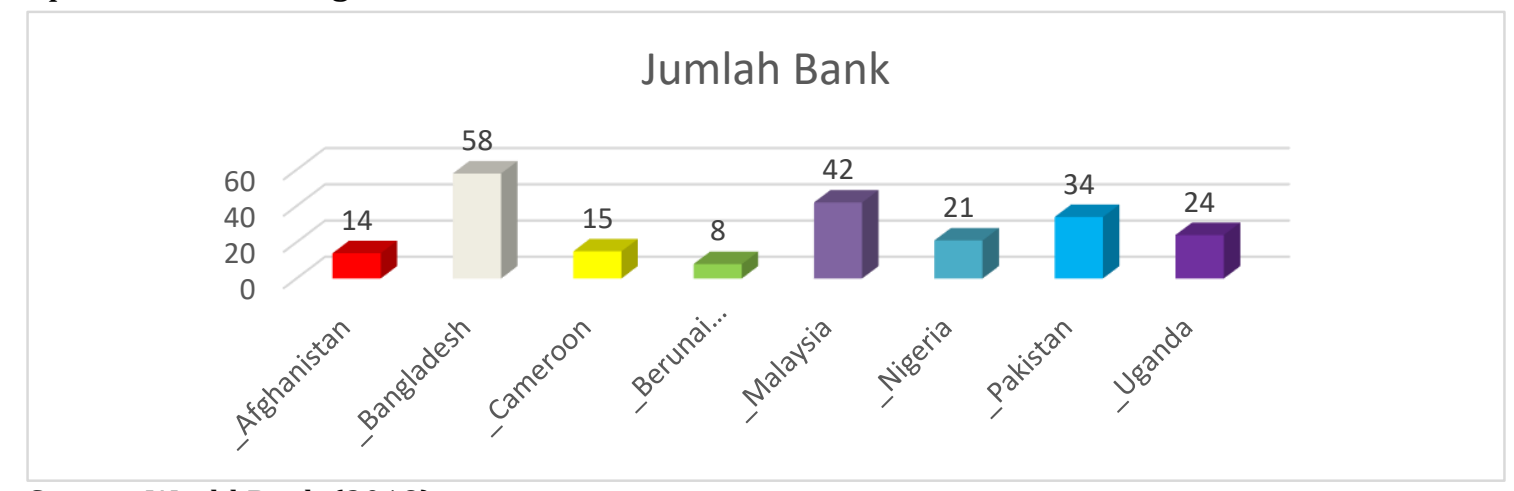

Source: World Bank (2018)

\section{Figure A.3: Number of OIC State Commercial Banks in 2018}

Based on World Bank data in 2018, Banglades has 58 commercial banks while Malaysia, Pakistan, Uganda, Nigeria, Cameroon, Brunei Darussalam, and Afghanistan have fewer than 50 commercial banks. According to the World Bank database, access to finance in OIC countries increased significantly over the years, increasing from $27.8 \%$ in 2011 to $46.3 \%$ in 
2017. But when compared to other groups of countries, they remain far behind the average group of countries (SESRIC, 2019).

The large role of the development of the financial sector and the macro situation of a country in the withdrawal of foreign capital flows, has been a serious concern by academics, practitioners, and investors recently. Financial sector development consists of capital and banking markets that can be reflected by financial inclusion which is an important indicator in the role of FDI withdrawal in a country. That is because financial inclusion acts as an incentive and signal of economic stability for foreign investors who are interested in investing in direct form such as in the production and infrastructure development sector (Qamruzzaman \& Jianguo (2019). In addition, macroeconomic conditions such as inflation, interest rates and GDP growth of a country also play an important role in the withdrawal of FDI (Demirhan \& Mahmut, 2008; Qamar, 2019). However, in some OIC countries there is a discrepancy that shows that FDI plays a big role in economic growth, while the inclusion rate is still low.

The purpose of this study is to investigate the influence of financial inclusion and macroeconomic conditions on foreign direct investment (FDI) in several countries of the Organization of Islamic Cooperation (OIC) during the period 2012-2018. In this study, there were 8 OIC member countries sampled in the study, namely two Southeast Asian countries (Indonesia and Malaysia), three South Asian countries (Pakistan, Afghanistan and Bangladesh), while from Africa there were three countries namely Cameroon, Uganda and Nigeria. The selection of OIC member states is based on data limitations on the variables used.

\section{Literature Review}

\section{Financial Inclusion}

Financial inclusion is the ease of access, availability, and benefits of the formal financial system for all economic actors (Sarma, 2012). Financial inclusion connects people, especially the poor, into the formal banking system with safe, easy and affordable access to credit and other financial services (Sarma \&Pais, 2011). Financial inclusion is closely related to well-being, some empirical studies show a positive relationship between financial system development and economic growth in the long run. Levine (1998; 1999), and Demirguckent et al (2008) found financial inclusion had an impact on decreasing income inequality (coefficient of gini), increasing the incomes of the poor, and lowering the percentage of poverty. This is because of the increasingly open access to financial services, the public will use the funding support in the form of credit to help in improving the productivity of their 
business or business.

In the measurement of financial inclusion, there are various methods of approach to facilitate the measurement, one of which is by using indexes. Sarma (2012), Gupta et al. (2014), Sanjaya and Nusechafia (2016), using index of financial inclusion (IFI) with three dimensions namely accessibility, availability and usage dimension. This study does not use indexes but only uses indicators of dimensions suggested by Sarma (2012) namely banking penetration, availability of banking services and usability. The three-dimensional adjustment used consists of:

a. Dimensions of Accessibility

The dimension of accessibility makes the number of deposit accounts as a measure of banking penetration. The measurement of accessibility dimension uses the ratio of the number of savings deposits of banks compared to 1,000 adult population.

b. Dimension of Availability

This dimension is used as a gauge of the ability of formal financial services in providing easy access to services to the community. In this dimension seen is how many banking facilities are able to provide service access offers to the community. The number of banking branch offices per 100,000 population, is used as an indicator in this dimension.

c. Dimensions of Use

The use of this dimension as a gauge of the function of Sharia banking as a financial intermediation institution for the general public. The indicators used are the volume ratio of two basic services on the banking system, namely credit and deposit of the number of adult population to the value of GDP.

\section{Financial Inclusion and FDI}

Foreign Direct Investment (FDI) is one of the types of foreign capital flows recognized as the capital transfer that contributes the most to improving economic growth compared to external assistance and money transfer into the country. That is because the flow of FDI is always production-oriented and becomes a medium of technology transfer and management skills and also creates jobs. FDI inflows also have long-term investment prospects so that in its operations, the turnover of foreign capital in the country is considered more economically profitable for the host country. Some previous studies have mentioned that economic freedom, especially in the aspects of a country's trade policy, banking and financial services and property protection have an important role in improving the performance of FDI in developing countries (Globerman \&Shapiro, 2003).

Capital flows are strongly driven by an optimistic view of investment opportunities in 
the host economy. Financial inclusion has a role in maintaining the financial stability of a country, because access to financial services, especially to bank-based financial institutions by the public helps in accumulating capital and increasing the possibility of additional income. Lusiyana (2002) explained that the efficiency of local financial markets and economic growth play a deterministic role in attracting foreign capital flows. The expansion of the banking sector in the financial system allows for greater capital and investment in the economy by enabling the provision of liquidity in the financial system that demonstrates financial efficiency in the economy, accompanied by institutional efficiency. With such efficiency becomes an optimistic view for investors and plays an increasingly intensive role in attracting foreign capital flows in the economy (Diamond \& Dybvig, 1983).

So far no conclusive evidence has emerged in the existing literature to answer questions about the most important factors in foreign capital flows. However, some researchers claim the development of the host country's financial sector is a major factor as a puller of foreign capital flows (Baltagi et al., 2009). Financial sector development consists of capital market and banking sector. In research of Poelhekke (2015) found that bank-based financial institutions operating in both central and foreign banks accelerate foreign capital flows by facilitating financial transactions efficiently. In addition, Qamruzzaman and Jianguo (2019) stated that financial inclusion acts as an incentive and signal of economic stability for foreign investors interested in investing in direct forms such as in the production and infrastructure development sectors.

H1: Financial inclusion positively affects FDI

\section{Macroeconomics}

Macroeconomic discussion is a study of economics that studies economic events and problems as a whole and aggregated (Nanga, 2001). In general, macroeconomics explain the economic changes that have a wide impact both on society, companies and markets. Macroeconomic issues can be divided into issues such as inflation and deflation, exchange rates, unemployment, interest rates, economic growth, income and expenditure, balance of payments, and money circulation within a country. Macroeconomics are very important for a country because macroeconomic balance can have a positive impact on a country's economy and can also adversely affect if the macro-economy is unstable.

\section{Interest Rate and FDI}

Interest rate is a cost burden set in order to borrow money for a certain period of time usually in the form of a certain percentage (Fabozzi \& Fancais, 2003). Bodie et al (2006) described interest rates as systematic risk factors that affect the investment value of debt 
securities and foreign investment. Because the investor will invest the funds if the rate of return offered exceeds or at least equals the prevailing interest rate. In other words, if the rate of return is less than the interest rate then the investor is reluctant to invest. This reasoning reinforces the theory that interest rates affect FDI inflows in a country (Sukirno, 2006). Some studies have found interest rates have a significant negative influence on FDI. Tulong et al. (2015) show that in the short term there is an insignificant negative relationship between interest rates and foreign direct investment but in the long run interest rates increase the flow of foreign direct investment (FDI). That is because when interest rates are high people will be motivated to save money to deposit products and delay secondary consumption. As a result, it will reduce the amount of money in circulation and transaction activity, so that activity in the real sector grows slowly and decreases the interest of foreign investors in investing in the country.

H2: Interest rates negatively affect FDI

\section{Inflation and FDI}

Inflation is a phenomenon when the price of goods and services in general increases continuously in a certain period of time (Kariem, 2010). The high state of inflation will complicate economic development, because rising prices of goods decrease people's purchasing power, thus negatively impacting productive activities. In addition to weakening domestic productive activities, rising prices of domestically produced goods will also complicate competition in the global market (Sukirno, 2006). An unstable economy due to too high inflation negatively impacts investment activities, as the cost of expensive investments is not offset by increased demand from consumers. This will affect the sentiment of foreign investors to invest in the country.

In addition, inflation has been hypothesized as well as distorting the tax system which in turn will deter investors for the long term due to the illusion of money (Omankhanlen, 2011). In this context, Andinuur (2013) conducted research to test the relationship between inflation, FDI, and economic growth in Ghana. Researchers state that the low inflation rate is indicative of internal economic stability in the host country and will in turn increase the return on foreign direct investment. Furthermore, the researchers explained that the low inflation rate in a country encourages FDI, where when the inflation rate is low, the nominal interest rate decreases and consequently the cost of capital becomes low. In addition, the availability of capital at low loan rates will allow foreign investors not only to find better partners in the host country, but will also maximize the return on their investment. In addition, Alguaci, Cuadros and Orts (2011) found that the inflation rate negatively impacted 
FDI in asean countries. The researchers explained that because inflation exceeds the threshold, it will negatively affect FDI inflows to the country.

H3: Inflation negatively affects FDI

\section{Exchange Rate and FDI}

According to Ekananda (2014) the exchange rate is the relative price of a country's currency against the currency of another country. Exchange rates play an important role in the open economy because of the huge impact on the current account balance and other macroeconomic variables. Benassy-Quere et al. (2001) suggests the impact of exchange rates on FDI depends on the type of investment (horizontal foreign direct investment or vertical foreign direct investment). In the case of horizontal foreign direct investment, exchange rate depression has a positive impact on FDI due to the reduction of costs to capital and if the exchange rate is appreciated it will also increase the flow of FDI because local consumers have high purchasing power. But in the case of vertical foreign direct investment, the appreciation of the host country's currency has a negative effect on FDI because locally produced goods will be expensive abroad. Meanwhile, if the exchange rate depreciates, it is positively correlated to increase the flow of FDI. Several previous studies supporting this theory, Morrissey et al. (2008) found that exchange rates when devaluation and appreciation have a negative and positive impact on FDI inflows in 16 developing countries in the United States. This is reinforced by the research of Alba et al. (2009).

H4: Exchange rate negatively affects FDI

\section{Economic Growth and FDI.}

Economic growth is the increase in the amount of production of goods and services in a country indicated in quantitative changes. Economic growth can be measured through the Gross Domestic Product (GDP) indicator which is a calculation of the number of goods and services in a country in a given period. Dunning (1981) in Tang (2007) mentioned that there is a relationship between economic development as one of the determining factors of FDI known as investment development path (IDP) theory. The level of national income is a reflection of the increase in people's income. High public income is positively correlated with increased consumption patterns and contributes to the company's revenue, thus encouraging investors to invest and develop the company (Sukirno, 2006). Several previous studies supporting the above theory include Tulong et al. (2015), Permana and Rivani (2013), Rasheed and Qamar (2019) finding that GDP will be significantly positively correlated to FDI inflows and vice versa. The smaller the economic growth rate of a country, it will decrease the value of FDI. 
H5: GDP positively affects FDI

\section{Data and Research Methodology}

Data

This study uses annual time series data, collected from world development indicators published by the World Bank (2019) and international financial statistics published by the International Monetary Fund (2019) for the period 2012-2018. Meanwhile, data representing macroeconomic authors using variable data on Inflation (IFL), Interest Rates (ITR), Exchange Rates (ER), and Economic Growth using Gross Domestic Products (GDP) were obtained from the Bank Indonesia Website. This study used research samples from several Oki countries including Afghanistan, Bangladesh, Cameroon, Brunai Darussalam, Malaysia, Nigeria, Pakistan, and Uganda.

\section{Research Methodology}

In this study the authors will use descriptive quantitative methods using panel data analysis tools. Panel data is data obtained from cross section data that is observed repeatedly on the same individual unit (object) at different times. This model has the advantage of being able to control unobserved heterogeneity, be more informative, learn more complex models, reduce comlinearity, increase the degree of freedom and be efficient and can measure the effect of a variable on other variables better than just using time series or cross section data so as to reduce bias in conclusion withdrawal (Junanda \&Junaidi, 2012).

The data panel regression model used in this study is as follows:

Model 1 Financial Inclusion to FDI:

FDI $=\beta_{0 \mathrm{i}}+\beta_{1}$ Akses $_{\text {it }}+\beta_{2}$ Avalibitas $_{\text {it }}+\beta_{3}$ Use $_{\text {it }}+\varepsilon_{\text {it }}$

Model 2 Macro Variables to FDI:

FDI $=\beta_{0 \mathrm{i}}+\beta_{1} \mathrm{IFL}_{\mathrm{it}}+\beta_{2} \mathrm{ITR}_{\mathrm{it}}+\beta_{3} \mathrm{ER}_{\mathrm{it}}+\beta_{4} \mathrm{GDP}_{\mathrm{it}}+\varepsilon_{\mathrm{it}}$

Where:

FDI : Foreign direct investment

Access : Number of depositors/1,000 adults

Availability: Number of bank branch offices/100,000 adult residents

USE : Percentage of bank financing compared to GDP

FDI : Foreign direct investment

IFL : Inflation

ITR : Interest rate

ER : Exchange rate 
GDP : Gross domestic product

I : Number of countries

$\mathrm{T} \quad$ : Amount of time (annual)

B_0i : Intercession coefficient

$\beta \_1, \beta \_2, \beta \_n:$ Slope coefficient

$\varepsilon \quad$ : Error

In this model there are three approaches in the calculation of the data panel regression model, namely the simple common-constant method or Pooled OLS method (PLS), fixed effect method or Fixed Effect (FEM), and finally random effect method or Random Effect (REM). After performing these three methods, the best method is selected to estimate the regression model. The selection includes Uji-Chow for selection between PLS and FEM methods, Lagrange Multiplier Test (LM) for selection between PLS and REM and Hausman Test for selection between FEM and REM.

\section{Results and Discussion}

Financial Inclusion

To measure the level of financial inclusivity can generally be characterized by the amount of use of banking services and see how affordability of formal financial institutions at all levels of society. Because the easier it is for people to access finance, the higher the level of financial inclusion of the country (Inoue \&Hamori, 2016). The variable the researchers used to reflect that accessibility was the number of depositors per 1,000 adult population. As for variable availibitas use the availability of banking branch offices per 100,000 adult residents. And for variable usefulness researchers use total banking financing per GDP.

Table 1.0IC Countries Average Financial Inclusion Data for 2012-2018

\begin{tabular}{lccc}
\hline Country & $\begin{array}{c}\text { Number of } \\
\text { Depositors/1,000 } \\
\text { Adults }\end{array}$ & $\begin{array}{c}\text { Number of } \\
\text { Branches/100,000 } \\
\text { adults }\end{array}$ & $\begin{array}{c}\text { Percentage of Bank } \\
\text { Financing Credit/GDP }\end{array}$ \\
\hline Afghanistan & 170.009 & 2.16340471 & 3.535322 \\
\hline Bangladesh & 642.5528 & 8.56937314 & 41.08386571 \\
\hline Cameroon & 80.55833 & 1.98764043 & 15.13816714 \\
\hline Malaysia & 749.5655 & 10.6339043 & 111.5771 \\
\hline Nigeria & 766.4564 & 5.2465365 & 13.27630286 \\
\hline Pakistan & 310.8498 & 19.2673857 & 17.37156143 \\
\hline $\begin{array}{l}\text { Berunai } \\
\text { Darussalam }\end{array}$ & 1548.164 & 20.2663243 & 28.30714429 \\
\hline Uganda & 246.7592 & 4.65481275 & 13.45822857 \\
\hline
\end{tabular}

Data Source: World Bank (2019) 
High-income countries are generally higher and more constant depositors than lowincome countries. From World Bank data on the average number of depositors per 1,000 adults, Brunei Darussalam occupies the highest position of 1,548, as well as for the number of branches per 100,000 adults. While on variable percentage of the amount of financing per GDP Malaysia is the most is $111 \%$ of the country's GDP. While in low-income countries such as Afghanistan, Cameroon, and Uganda there are fewer than 400 depositors per 1,000 adult populations, then no more than 5 bank branches per 100,000 adults and total bank financing loans are less than $20 \%$ of the country's total GDP.

\section{Macroeconomics}

Macroeconomics explains the economic changes that have a wide impact on society, companies and markets. In investment theory the state of macroeconomics has an influence on the performance of investment in a country (Tandelin, 2010). In this study, macro variables were used, namely inflation, interest rates, exchange rates and GDP in eight OIC member countries. For variables the interest rate has an average value of $7.5 \%$ and a minimum and maximum value of $-3.4 \%$ and $27.8 \%$ respectively with a standard deviation of $5.7 \%$. This implies that the difference in interest rates between countries is quite high. Meanwhile, inflation in OIC countries averaged $4.7 \%$, while the minimum value and maximum were $-1.2 \%$ and $16.5 \%$ respectively and standard deviation was $3.9 \%$. That means inflation is fairly normal and stable. For variable exchange rates per US dollar the average obtained is 514.2191 units with a standard deviation of 1005.817 , with a minimum value of 1.249567 and a maximum of 3727.069 . The figures show the purchasing power of the OIC country's local currency against the dollar varies greatly. While the average GDP value is 197,889 MILLION US dollars and the minimum amount is 11,400 Million US dollars and the maximum value reaches 568,498 Million dollars and with a standard deviation of 155,981 MILLION US dollars. This explains that the difference in GDP level of each OIC country is quite large even though the majority of the sample is developing countries such as Afghanistan, Bangladesh, Cameroon, Brunai Darussalam, Malaysia, Nigeria, Pakistan, and Uganda.

\section{Statistical Data Processing Results}

Financial Inclusion of FDI in OIC countries

The data regression panel results using three approaches namely common Effect Model, Fixed Effect Model and Random Effect Model. The regression results of the three inclusion variables were tested: 
Table 2. Financial Inclusion Panel Data Regression Results to FDI

\begin{tabular}{lccc}
\hline Variable & Commond Effect & Fixed Effect & Random Effect \\
\hline C & 2015.089 & 2014.779 & 2015.089 \\
\hline Akses & $-1.37 \mathrm{E}-10$ & $-2.87 \mathrm{E}-10$ & $-1.37 \mathrm{E}-10$ \\
\hline Avaibilitas & 0.002412 & 0.012040 & 0.002412 \\
\hline USE & -0.129301 & -0.739910 & -0.129301 \\
\hline \multicolumn{4}{c}{ Effect Spesification } \\
\hline R-square & 0.082043 & 0.334737 & 0.082043 \\
\hline $\begin{array}{l}\text { Adjusted } \\
\text { R-squared }\end{array}$ & 0.029084 & 0.186901 & 0.029084 \\
\hline F-statistic & 1.549183 & 2.264245 & 1.549183 \\
\hline
\end{tabular}

From the results of the regression of the panel data above shows that the highest

R-Squared value is by using a Fixed Effect Model of 33.47\%. Eat this research using the Fix Effect Model (FEM). This study has also conducted the selection of the best models based on models that have been tested including CEM with FEM and FEM with REM, the most appropriate model used in this study is the result of regression with Fixed Effect Model (FEM).

\section{Uji Chow Test}

The result of regression between the common effect model and fixed model, the following results are obtained:

Table 3. Chow Financial Inclusion Test to FDI

\begin{tabular}{lccc}
\hline Effect Test & St. & d.f & Prob \\
\hline Cross-section f & 2.441835 & $(7,45)$ & 0.0328 \\
\hline $\begin{array}{l}\text { Cross section Chi- } \\
\text { square }\end{array}$ & 18.030220 & 7 & 0.0118 \\
& & &
\end{tabular}

Based on the table above the regression result shows the probability value of Chisquare $<0.05$ which is 0.0328 . Thus, the conclusion that zero hypothysis (H0) is rejected, then with the best model dimikian between CEM and FEM is the FEM model. Because the model chosen fem model then conducted the next test that is Hausman test.

\section{Hausman Test}

Hausman test was conducted for the selection of the most appropriate model between the FEM and REM models. 
Table 4. Hausman Financial Inclusion Test Results to FDI

\begin{tabular}{lccc}
\hline Test Summary & $\begin{array}{c}\text { Chi-sq. Sttistik } \\
\text { Chi-sq }\end{array}$ & d.f & Prob \\
\hline Cross-section f & 17.092842 & 3 & 0.0007 \\
\hline
\end{tabular}

Based on table 4 above hausman test result obtained probability value of Crosssectioan random $\mathrm{F}$ of $0.0007<0.05$. Then the test results reject $\mathrm{H} 0$ which means the Fixed Effect model is better used. From the chho test and hausman test above, the best model used is the Fixed Effect model.

Table 5. Data Regression Results Panel Fix Effect Financial Inclusion Model to FDI

\begin{tabular}{lcccc}
\hline Variable & \multicolumn{4}{c}{ Regression Model } \\
\cline { 2 - 5 } & Coefficient & t-statistic & Prob. & Conclusion \\
\hline Access & $-2.87 \mathrm{E}-10$ & -1.10301 & 0.2759 & No Significant \\
\hline Avaibility & 0.012040 & 3.862426 & 0.0004 & Significant \\
\hline USE & -0.73991 & -1.553432 & 0.1273 & No Significant \\
\hline Adj. R-squared & 0.186901 & & & \\
Prob (F-Statistik) & 0.030384 & & Significanse Level $\alpha 0.05$ \\
\hline
\end{tabular}

Financial inclusion significantly impacted FDI in the sample country during the period 2012-2018. This is indicated by the prob F-statistical value of 0.030384 . From the adjusted value R2 can explain the inclusion of quandary in OIC countries affects by $18 \%$ against the inflow of FDI, while $82 \%$ is influenced by other variables outside the model. This is in line with research of Qamruzzaman and Jianguo (2019) which has proven the development of financial inclusion encourages foreign capital flows in the form of FDI in 58 developing countries. In general, financial inclusion plays an important role in encouraging foreign investors through greater expansion of financial services in the financial system, along with easy access to financial benefits.

Based on the results of the t-tests in the table above shows that only the variable avaibility (number of branches per 100,000 adults) has a significant positive influence on FDI this is indicated from the t-statistics of 3.862426 and the significance or probability of 0.0004 or less than $\alpha=0.05$. While access and USE variables do not have a significant effect on FDI because the probability or 
significance value exceeds $\alpha=0.05$. This indicates that when the number of bank branches increases, it will certainly make it easier for people to reach financial services and products so that financial functions are more stable. In addition, investors are also more flexible in allocating funds to the production sector because the process of withdrawing money from banks as intermediaries can be easier.

\section{Macroeconomics to FDI in OIC Countries}

From the Table 6 shows that the highest R-square value by using the Fixed Effect Model method is $38.82 \%$. So this study uses Fixed Effect Model, with R-square value of 0.3882 or $38.82 \%$. This study has conducted the best model selection test by conducting a test of the selection between CEM with FEM and FEM with REM, the most appropriate model used in this study is the result of regression model with Fixed Effect Model.

Table 6. Microeconomic Panel Data Regression Results to FDI

\begin{tabular}{lccc}
\hline Variable & $\begin{array}{c}\text { Commond } \\
\text { Effect }\end{array}$ & Fixed Effect & Random Effect \\
\hline C & 2014.671 & 2003.106 & 2014.671 \\
\hline IR & $-4.16 \mathrm{E}-10$ & 0.395488 & $-4.16 \mathrm{E}-10$ \\
\hline INFLATION & 0.003466 & -0.156915 & 0.003466 \\
\hline KURS & -0.151077 & -0.263846 & -0.151077 \\
\hline GDP & 0.031396 & 0.004423 & 0.031396 \\
\hline R-square & Effect Spesification & \\
\hline Adjusted R-squared & 0.173526 & 0.388276 & 0.173526 \\
\hline F-statistic & 0.108704 & 0.235345 & 0.108704 \\
\hline U & 2.676976 & 2.538899 & 2.676976 \\
\hline
\end{tabular}

\section{Uji Chow Test}

This test is conducted for the selection of models between common effect models with fixed models, as for the results of regression of this model as follows:

Table 7. Test Chow Macroeconomics to FDI

\begin{tabular}{lccc}
\hline Effect Test & St. & d.f & Prob \\
\hline Cross-section f & 2.877321 & $(7.44)$ & 0.0145 \\
\hline $\begin{array}{l}\text { Cross section Chi- } \\
\text { square }\end{array}$ & 21.106290 & 7 & 0.0036 \\
\hline
\end{tabular}

Based on the table above the analysis results show the probability value of ChiSquare $<0.05$ which is 0.0145 . Thus, the conclusion that the zero hypothesis $(\mathrm{H} 0)$ is 
rejected means that a better model is used is the Fixed Effect model. Because it uses fixed effect model, it is done by lantjutan test using Hausman test.

\section{Hausman Test}

Hausman's test was conducted for the selection of the most appropriate model used between FEM and REM.

Table 8. Results of Hausman Macroeconomic Test to FDI

\begin{tabular}{lccc}
\hline Test Summary & $\begin{array}{c}\text { Chi-sq. Sttistik } \\
\text { Chi-sq }\end{array}$ & d.f & Prob \\
\hline Cross-section f & 20.141249 & 4 & 0.0005 \\
\hline
\end{tabular}

Based on the table above Hausman test results show that the probability value of Csoss-section random $\mathrm{F}$ of 0.0005 test results reject $\mathrm{H} 0$ which means fixed effect model is better used, deri chow test test and hausman test above, the best model chosen in this study is fixed effect model.

Table 9. Data Regression Results Panel Fix Effect Macroeconomic Model to FDI

\begin{tabular}{|c|c|c|c|c|}
\hline \multirow[t]{2}{*}{ Variabel } & \multicolumn{4}{|c|}{ Model Regresi } \\
\hline & Coefficient & t-statistic & Probabilitas & Conclusion \\
\hline IR & 0.395488 & 3.456356 & 0.0012 & Significant \\
\hline Inflation & $\begin{array}{c}- \\
0.156915\end{array}$ & $\begin{array}{c}- \\
2.419159\end{array}$ & 0.0198 & Significant \\
\hline Exchange Rate & $\begin{array}{c}- \\
0.263846\end{array}$ & $\begin{array}{c}- \\
2.069347\end{array}$ & 0.0444 & Significant \\
\hline GDP & 0,004423 & 3.193853 & 0.0026 & Significant \\
\hline $\begin{array}{l}\text { Adj.R-Squared } \\
\text { Prob(F-Statistik) }\end{array}$ & $\begin{array}{l}0.235345 \\
0.014074\end{array}$ & \multicolumn{3}{|c|}{ Significance Level $\alpha 0,05$} \\
\hline
\end{tabular}

From the results of the regression of the data panel above shows on macroeconomic variables against FDI, the best model selected using fix effect model (FEM). Overall macroeconomic variables significantly affected FDI in OIC sample countries during the period 2012-2018. This is indicated by the prob F-statistical value of 0.030384 . Meanwhile, based on the adjusted value of R2 which is 0.235345 , so that it can be concluded that independent macroeconomic variables such as interest rates, inflation, exchange rates and GDP in 8 OIC countries can explain the impact on FDI during the period 2012-2018 of 23\%, while the rest is explained by other variables outside the model. 
The result of variable inters rate (IR) data or positive significant interest rate with t-statistic 3.456356 with a probability significance value of 0.0012 is less than $\alpha=0.05$. This rejects the hypothesis that interest rates negatively affect FDI. This is because the average sample country has low interest rates and is stable enough to motivate customers to borrow capital and divert to the real sector so that economic growth is stable and foreign investors view positively. This study is in line with the findings of Emanuel et al. (2019) which found that interest rates in the long run have a positive effect on FDI.

In variable inflation has a t-statistic of -2.419159 with a significance of 0.0198 smaller than $\alpha=0.05 \%$ so that the inflation rate has a negative relationship and has a significant effect on the flow of FDI in OIC countries. This is because when the inflation rate is too high of course the purchasing power of the public will decrease, thus reducing the company's income and resulting in a decrease in economic growth and giving rise to a negative view of foreign investors to invest long-term in the form of FDI. This is in line with the research of Xaypanya et al (2014) which also found that inflation has a significant negative influence on FDI in ASEAN countries.

While the variable exchange rate also has a significant negative effect on FDI indicated from the $t$-statistical value -2.069347 with a probability significance of 0.0444 less than $\alpha=0.05$. This is because the exchange rate of the sample country is still weak against the dollar and fluctuating high. Because when it is too high of course raw materials imported from abroad will be more expensive and therefore the goods produced in export will certainly be more expensive so that the competitiveness abroad is weak. This is in line with lily et al. research (2014) which found that when the purpose of investment to export products abroad, the exchange rate will have a significant negative effect on FDI because the price of such goods will be more expensive so it is difficult to compete with foreign products.

For variables of economic growth projected by GDP, the t-statistical value indicates a positive relationship with the value of 3.193853 and significant a probability of 0.0026 smaller than $\alpha=0.05$. That means economic growth in OIC sample countries has an impact on increasing FDI flows into the country. This is because when the economic growth of the host country has progressed well and stable development will encourage the desire of investors to invest their funds in 
the country because investor decisions are largely determined by an optimistic view of the host's investment opportunities. This research is in line with research by Rasheed and Qamar (2019) which proves GDP plays a significant positive role in FDI flows in ASEAN countries.

\section{Conclusions and Suggestions}

\section{Conclusion}

The study found that financial inclusion has a significant positive relationship to the growth of FDI fund flows. This can be explained because financial inclusion through the addition of bank branches acts as an incentive for foreign investors especially in the production sector and infrastructure because the process of withdrawing money from banks as intermediaries can be easier. In addition, the addition of the number of bank branches will certainly facilitate the public in reaching financial services and products so that financial functions are more smooth and stable. The findings of research on macroeconomics also have a close relationship with FDI withdrawals, such as interest rates that have a significant positive influence on FDI through credit products with interest rates that are relatively still in the single digits turned out to be a stimulus in driving economic growth. While inflation and exchange rates have a significant negative influence because the increase in the price of goods and the dollar triggers the increase in production costs so that the price of goods produced is also expensive and difficult to compete with foreign products. While economic growth is positively correlated significantly in attracting FDI. This is because good economic growth will be an optimistic hope for foreign investors to invest their funds into OIC countries.

\section{Suggestions}

This study is still experiencing limited data on the countries of the Organization of Islamic Cooperation that became a sample of the study, so it is expected that the next researchers to explore more OIC countries so that the withdrawal of conclusions is more accurate. In addition, researchers are further advised to develop research using the Islamic financial inclusion index because given the rapid growth of the Islamic financial sector in these OIC countries. The study found that further increases in financial inclusion specific to Avaibility or an increase in the number of bank branches led to continued ease of FDI inflows. Therefore the government and 
financial authorities should pay great attention to the development of the financial sector and simultaneously formulate policies aimed at improving financial inclusiveness in OIC countries. In addition, the government also needs to maintain macroeconomic stability in the country both with low interest rates, low inflation, stable exchange rates and progressive economic growth as well as other macro policy policies that support the ease of FDI withdrawal into the OIC country.

\section{REFERENCES}

Adam, Anokye M. and Tweneboah, George. (2009). Foreign Direct Investment and Stock Market Development: Ghana's Evidence. International Research Journal of Finance and Economics, Vol. 26, pp. 178-185.

Akay, H., Karaköy Ç., (2008). The role of international accounting standards in foreign direct investment and foreign direct investment in Kyrgyzstan. International Capital Movements and Emerging Markets International Symposium. Bandırma: Balıkesir University, Bandırma İ̈BF, 68-78.

Alba, J. C. (2009). Ascariasis lumbricoides and Ascaris suum: A Comparison of Electrophoretic Banding Patterns of Protein Extracts from the Reproductive Organs and Body Wall. Vaterinarski Arhiv 79(3). p. 281-291

Al Nasser, O.M. and Soydemir, G. (2010) Domestic and International Determinants of Foreign Direct Investment in Latin America. FMA Annual Meeting, New York.

Alguacil, M., Cuadros, A., \& Orts, V. (2011). Inward FDI and Growth: The Role of Macroeconomic and Institutional Environment. Journal of Policy Modeling, 33, 481496.

Andinuur, J. (2013). Inflation, Foreign Direct Investment and Economic Growth in Ghana. Master Thesis. University of Ghana, available at: http://ugspace.ug.edu.gh.

Baltagi B.H., Demetriades P.O., Law S.H. (2009). Financial development and openness: Evidence from panel data. J Dev Econ 89: 285-296.

Bodie, Kane. \& Marcus, A. J. (2006). Investasi. Edisi ke enam. Terjemahan. Jakarta: Salemba Empat.

Benassy-Quere, A.,Fontagne,L. dan Lahreche-Revil, A. 2001. Exchange-Rate Strategies in the Competition for Attracting Foreign Direct Investment. Journal of the Japanese and International Economies, 15,178-198

Demirguc-Kunt A, Beck T, Honohan P. (2008). Finance for All Policies and Pitfalls in Expandin Access, Washington, DC (US): World Bank. 
Demirhan, E., \& Mahmut, M. (2008). Determinants Of Foreign Direct Invesment Flows Analysis. Prague Economic papers, 356-369.

Diamond, D. W., Dybvig, P. H. (1983) Bank runs, deposit insurance, and liquidity. J Polit Econ 91: 401-419.

Ekananda Mahyus. 2014. Ekonomi Internasional. Jakarta: Erlangga.

Fabozzi, Frank J. and Peterson, Pamela P. 2003. Financial Management and Analysis. New Jersey: Scond Adition, John Wiley \& Sons, Inc. Hoboken.

Fedderke, J. W., \&Romm, A. T. (2006).Growth impact and determinants of foreign direct investment into South Africa, 1956-2003.Economic Modelling, 23(5), 738-760.

Gerard, A., Tulong, S., \& Topowijono. (2015). Analisis Pengaruh Makro Ekonomi Terhadap Keputusan Investasi Asing Di Indonesia. Jurnal Administrasi Bisnis (JAB) Vol. 22 No. 2 $1-8$

Globerman \& Shapiro, (2003). Governance Infrastrukture and US foreign direct investment. Journal of International Business Studies is currently. Vol.34, issue 1, 19-39

Gupta, Aurag, et al. (2014). Financial Inclusion and Human Development: A State-Wise Analysis From India. International Journal of Economics, Comerce and Management.

Inoue, T., \& Hamori, S. (2016). Financial access and economic growth: Evidence from SubSaharan Africa. Emerging Markets Finance and Trade, 52(3)

Juanda, Bambang dan Junaidi. 2012. Ekonometrika Deret Waktu Teori dan Aplikasi. Bogor: IPB Press

Karacan, A. İ., 1997. Finans, ekonomi ve politika. Creative Yayıncılık, Istanbul.

Karim, Adiwarman. 2010. Bank Islam (Analisis Fiqih dan Keuangan). Jakarta: PT. RajaGrafindo Persada

Levine, R. (1997). Financial Development and Economic Growth: Views and Agenda. Journal of Economic. Literature, 35, 688-726.

Lily. J., Kogid. K., Mulok. D., Sang. L.T., and Asid. R. (2014). Exchange Rate Movement and Foreign Direct Investment in Asean Economies. Hindawi Publishing Corporation Economics Research International Volume 2014, 1-10.

Morrissey. O., and Mongkol. M.U., (2008) Foreign Direct Investment and Exchange Rates: A case Study of US FDI in Emerging Market Countries. Journal of School of Economics, University of Nottingham and Bank of Thailand.

Nanga, Muana. (2001). Makro Ekonomi, Teori, Masalah dan Kebijakan. Edisi Perdana. Jakarta: PT. Raja Grafindo Persada. 
Omankhanlen, Alex Ehimere. (2011).The Effect of Exchange Rate and Inflation on Foreign Direct Investment and Its Relation with Economic Groth in Nigeria. Valley International Journal. No.11.

Permana, S. H., \& Rivani, E. (2013). Pengaruh Produk Domestik Bruto, Inflasi, Infrastruktur, Dan Risiko Politik Terhadap Investasi Langsung Asing Di Indonesia. Jurnal Ekonomi \& Kebijakan Publik, Vol. 4 No. 1, 75 - 87.

Poelhekke, S. (2015) Do global banks facilitate foreign direct investment? Eur Econ Rev 76: $25-46$.

Qamar, R. (2019). Macroeconomic Factors Of Fdi Inflows In Asian Economies: A Study Of 14 Asian Countries.International Jpurnal of Advanced Reseachr (IJAR). ISSN: 2320-5407 Int. J. Adv. Res. 7(2), 289-300.

Qamruzzaman, M., \& Wei, J. (2019). Do financial inclusion, stock market development attract foreign capital flows in developing economy: a panel data investigation. Quantitative Finance and Economics, 88-108.

Rasheed, Q., (2019). Macroeconomic Factors of Fdi Inflows In Asian Economies: A Study of 14 Asian Countries. International Journal of Advanced Research. 7(2), 289-300.

Sanjaya, Made I dan Nursechafia. 2016. Inklusi Keuangan Dan Pertumbuha Inklusif: Analisis Antar Provinsi Di Indonesia. Buletin Ekonomi Moneter dan Perbankan, Volume 18, Nomor 3

Sarma, M. (2012). Index of Financial Inclusion-A Measure of Financial Sector Inclusiveness. Centre for International Trade and Development. School of International Studies Working. Paper Jawaharlal Nehru University. Delhi, India.

Sudarsono, H. (2008). The Determinants of FDI Flows In OIC Countries. Jurnal ekonomi Pembangunan. Vol. 13 No.3.

Sukirno, S. (2006). Makroekonomi: Teori dan Pengantar. Edisi ketiga. Jakarta Indonesia: Raja Grafindo Persada.

Tajgardoon, G., Noormohamadi, K., \& Behname, M. (2015). Foreign Direct Investment and Islamic Banking: A Granger Causality Test. Economics and Finance Review, 8-13

Tang, S. (2007). Foreign Direct Investment and Its Impact in China: A Time Series Analysis. Submitted in Fulfillment of the Requirements of the degree of Doctor of Philosophy. Griffith: Department of International Business and Asian Studies, Griffith Business School, Griffith University.

Tandelilin, E. (2010). Analisis Investasi dan Manajemen Portofolio. Edisi 1. Yogyakarta: BPFE. The Statistical, Economic and Social Research and Training Centre for Islamic Countries (SESRIC), (2019). 
Tulong, G.A., Suhadak. (2015). Analisis Pengaruh Makro Ekonomi Terhadap Keputusan Investasi Asing Di Indonesia (Studi Pada Bank Indonesia Periode 2005-2013). Jurnal Administrasi Bisnis (JAB)|Vol. 22 No. 2 M.

World Bank Report. (2011). United State, New York.

Xaypanya, p., R. Poomthan dan Paweenawat, S. W. (2014). The determinants of Foreign Investment in ASEAN: the First differencing panel data analysis. International Journal of Social Economics, 43(3), 239-250. 